\title{
Jurisdiction by Estoppel in the International Court of Justice
}

International law has long recognized the doctrine of estoppel, a principle which prevents states from acting inconsistently to the detriment of others. ${ }^{1}$ Until recently, the use of estoppel in international law was limited to cases involving territorial claims, where the World Court ${ }^{2}$ had apphed estoppel five times. In November 1984, however, the Court twice applied the doctrine-without specifically identifying it as suchagainst the Umited States in finding jurisdiction over a Nicaraguan claim. ${ }^{3}$ The Court did so without explanation, analysis of the principle's elements, or discussion of the ramifications of such an extension.

There are two primary reasons why estoppel should not apply to jurisdiction. First, estoppel would allow the Court to claim jurisdiction in contravention of its own rules. Second, jurisdiction by estoppel might vitiate a state's right to withhold consent to jurisdiction, thus imdermining the foundation of international jurisdiction.

Part I of this Comment will discuss the legal background of estoppel in the international regime. This discussion will include both a general, theoretical analysis of international estoppel as well as an examination of its application $\mathrm{m}$ the Pernanent Court of International Justice and the International Court of Justice (ICJ). Part II describes the facts and holdings in the Nicaragua case. These holdings and the broader implications of the application of estoppel to international jurisdiction are analyzed in Part III. Finally, Part IV concludes that the Court erred in applying estoppel in these circumstances and that, as a matter of pohicy, estoppel should not be used to estabhish jurisdiction in international proceedings.

\section{I \\ LEGAL BACKGROUND \\ A. Estoppel in International Law}

\section{Definitions and Origins}

The international rule of estoppel has a historic basis both in AngloAmerican common law and in the European civil law systems, which

1. See Rubin, The International Legal Effects of Unilateral Declarations, 71 AM. J. INT'L L. 1, $16,19-20$ (1977).

2. "World Court" refers both to the Permanent Court of International Justice (1922-1946) and to the International Court of Justice (ICJ) (1946-date).

3. Concerning Military and Paramilitary Activities in and Against Nicaragua (Nicar. v. U.S.), 1984 I.C.J. 392 (Nov. 26). 
have an analogous concept of "preclusion" or "foreclusion." 4 In many cases international tribunals have referred to estoppel, preclusion, or equivalent terms indiscriminately. ${ }^{5}$ Nonetheless, international estoppe ${ }^{6}$ differs from its common and civil law ancestors. The development of estoppel from a municipal into an international concept has broadened the principle so greatly that the analogy with municipal estoppel is misleading. ${ }^{7}$ Judge Alfaro of the International Court of Justice has observed that international estoppel does not precisely reflect either municipal estoppel or civil law preclusion. ${ }^{8}$

Pomeroy describes six elements of equitable and promissory estoppel in Anglo-American law: (1) There must have been conduct (acts, language, or silence) amounting to a representation or a concealment of material facts, (2) these facts must have been known to the estopped party at the time of the conduct, (3) the complaining party must not have known the truth concerning these facts at the time, (4) the estopped party must have intended or expected the conduct to be relied on, (5) there must have been rehiance by the complaining party, and (6) the complaining party must have changed his position for the worse. ${ }^{9}$ Application of these requirements has resulted im the formation of a technical and complex rule. ${ }^{10}$

In contrast, imternational estoppel draws more sweeping lines. MacGibbon observes that it "has been invoked ... with the emphasis ... upon an imsistence on good faith and equitable conduct coupled with a lively awareness of the dangers of adopting inconsistent attitudes at different times." 11 This good faith basis of international estoppel ${ }^{12}$ gives the principle greater dimension. The obligation to act $\mathrm{m}$ good faith is a general principle of law and hence is part of international law. ${ }^{13}$ Consequently, "modern opinion is tending to elevate the concept of estoppel to

4. Rubin, supra note 1 , at 16 .

5. Id.

6. Throughout this Comment, the estoppel used in international law is referred to as "international estoppel." Anglo-American common law estoppel is referred to as "municipal estoppel."

7. MacGibbon, Estoppel in International Law, 7 INT'L AND CoMP. L.Q. 468, 477 (1958).

8. Concerning the Temple of Preah Vihear (Cam. v. Thai.), 1962 I.C.J. 6, 39 (June 15).

9. 3 J. Pomeroy, A TReatise on Equity Jurisprudence $\S 805$ (5th ed. 1941).

10. MacGibbon, supra note 7, at 478; Rubin, supra note 1 , at 18.

11. MacGibbon, supra note 7, at 487; see also I. Brownlie, Principles of Public INTERNATIONAL LAW 638 (3d ed. 1979) ("A considerable weight of authority supports the view that estoppel is a general principle of international law, resting on principles of good faith and consistency, and shorn of the technical features to be found in municipal law." (footnote omitted)).

12. See Bowett, Estoppel Before International Tribunals and Its Relation to Acquiescence, 33 BRIT. Y.B. INT'L L. 176, 176 (1957) ("The basis of the rule [of estoppel] is the general principle of good faith . . . "); MacGibbon, supra note 7, at 487; Rubin, supra note 1, at 2.

13. Certain Norwegian Loans (Fr. v. Nor.), 1957 I.C.J. 9, 53 (July 6) (Separate Opinion of Judge Lauterpacht). 
the rank of one of the 'general principles of law recognized by civilized nations. " 14 In particular, estoppel is widely recognized to apply in ICJ proceedings. ${ }^{15}$ The lack of technical rules governing the international concept may allow it to apply to increasingly wider varieties of cases. ${ }^{16}$ Moreover, because the scope of the doctrine has not been clearly defined, World Court judges are able to restrict or limit, as well as expand, the doctrine.

While good faitl forms the conceptual basis for international estoppel, the promotion of consistency provides its practical purpose. ${ }^{17}$ In international law, unlike tlie municipal context, no higlier government reigns over tlie parties; each sovereign stands on an equal footing with every other. ${ }^{18}$ Since no super-government can keep international relations smootli and stable, it is important for states to act in ways that conform to their previous positions. ${ }^{19}$ The World Court has noted: "Trust and confidence are inherent in international co-operation, in particular in an age wlien this co-operation in many fields is becoming increasingly essential." 20 Before one nation will rely on the pronounceinents of another, it inust believe that what is said today will not be demied tomorrow.

International estoppel, then, is based on good faitli and promotes consistency in international relations. It is a broad concept, capable of myriad applications, and as a "general principle of law recognized by civilized nations" it carries persuasive moral weight that can be applied in the International Court of Justice.

\section{Elements}

International estoppel requires satisfaction of three elements. First, the statement creating tlie estoppel must be clear and unambiguous; sec-

14. MacGibbon, The Scope of Acquiescence in International Law, 31 BRIT. Y.B. INT'L L. 143, 147-48 (1954); see also C. Jenks, The Prospects of International Adjudication 267-68 (1964). General principles of international law are "a source of law independent of convention and custom, as belonging in virtue of their social foundation and rational character to a common legal fund ...." C. DE Visscher, Theory and Reality in Public InTERnational Law 400 (rev. ed. 1968). The ICJ is required by its statute to apply general principles of law recognized by civilized nations. INTERNATIONAL COURT OF JUSTICE STATUTE art. 38.

15. See H. Lauterpacht, The Development of International Law by the Permanent Court of International Justice 83 (1934); MacGibbon, supra note 7, at 470; MacGibbon, supra note 14 , at 148.

16. MacGibbon, supra note 7, at 468. But see C. DE VISSCHER, supra note 14, at 401 ("In practice, however, a tribunal made up as the International Court of Justice is would probably rely only on [general] principles which, because of the universality of their recognition, could leave no grounds for any complaint of subjectivity.").

17. Bowett, supra note 12, at 186; MacGibbon, supra note 7 , at 468 .

18. C. DE VISSCHER, supra note 14 , at 16-19.

19. See MacGibbon, supra note 7 , at 478 .

20. Nuclear Tests (Austl. v. Fr.), 1974 I.C.J. 253, 268 (Dec. 20). 
ond, the statement must be voluntary, unconditional, and authorized; and finally, there must be good faith reliance upon the representation of one party by the other party either to the detriment of the relying party or to the advantage of the party making the representation. ${ }^{21}$ The first two elements have sparked hitle controversy; the third, however, has occasioned much debate.

In Concerning the Temple of Preah Vihear, ${ }^{22}$ Judge Alfaro indicated that international estoppel does not require rehance. ${ }^{23}$ However, none of the cited precedents supporting his claim involved a naked, unilateral declaration of intention. ${ }^{24}$ Moreover, Judge Alfaro was the only member of the Court who believed $\mathrm{m}$ the existence of an estoppel-like doctrine that did not require rehance. ${ }^{25}$

Judge Fitzmaurice took issue with Judge Alfaro's analysis, arguing that "the party invoking the rule must have 'relied upon' the statements or conduct of the other party, eitlier to its own detriment or to the otler's advantage." ${ }^{26}$ Furthermore, in the Nicaragua case, ${ }^{27}$ the ICJ reaffirmed the rehiance requirement, stating that "estoppel may be inferred froin the conduct, declarations and the like made by a State which ... [has] caused anotlier State or States, in reliance on such conduct, detrimentally to change position or suffer some prejudice."28

The reliance requirement may derive from the municipal law idea of detrimental reliance, but it performs an independent function in international law. Without it, international estoppel would severely limit the development of international policies by individual nations. States would feel bound to maintain outdated policies regardless of whether any other state had relied on the existence of those policies. ${ }^{29}$ As circumstances,

21. Bowett, supra note 12, at 188-94; accord A. VAMvoukos, TERMINATION OF TREATIES IN InTERnational LAW: The Doctrines of Rebus Sic Stantibus AND Desuetude 294 (1985); Brownlie, supra note 11 , at 638.

22. (Cam. v. Thai.), 1962 I.C.J. 6 (June 15).

23. Id. at 39-43 (Separate Opinion of Judge Alfaro). Although Judge Alfaro did not specifically refer to the reliance requirement, he discussed the binding nature of acquiescence-from which an estoppel may arise, see text accompanying notes $40-45$-at great length. By failing to mention the need for reliance even once, his statements indicate that he did not recognize the reliance requirement. For example: "Failure of a State to assert its right when that right is openly challenged by another State can only mean abandonment to that right." Id. at 40 .

24. Rubin, supra note 1 , at 17 .

25. Id. However, in a subsequent case, Nuclear Tests (Austl. v. Fr.), 1974 I.C.J. 253 (Dec. 20), the ICJ may arguably have applied estoppel without requiring reliance. See id. at 267-68; Franck, Word Made Law: The Decision of the ICJ in the Nuclear Test Cases, 69 AM. J. INT'L L. 612, 618 (1975).

26. Temple, 1962 I.C.J. at 63-64.

27. Concerning Military and Paramilitary Activities in and Against Nicaragua (Nicar. v. U.S.), 1984 I.C.J. 392 (Nov. 26).

28. Id. at 415 .

29. Rubin, supra note 1 , at 30 . 
understandings, and administrations change, foreign policy must be allowed to shift as well.

The rehance requirement is also supported by theoretical considerations. Estoppel is grounded on a need for good faith dealings among nations, but mere inconsistency does not necessarily imply a lack of good faith. ${ }^{30}$ A change in foreign policy usually does not, and should not, lead to international condemnation. If a nation changes its announced policy and thereby injures a third party, international accountability may be appropriate since, as one writer states, "the consequent change im the position of the parties means that in order to maintain good faith the party must stand by his representation." 31 However, if the complaiming party never relied on the statement and consequently did not change its position, the change in policy cannot be said to lack good faith.

\section{Form}

Claims of international estoppel arise im two contexts: unilateral declarations and acquiescence. Though facially dissimilar in some regards, the requirements and applications of estoppel are essentially the same in botli contexts.

\section{a. Unilateral Declarations}

A state inay act unilaterally in one of two ways: it may make a unilateral promise or it may make a unilateral statement of fact. Eitlier may give rise to an estoppel.

In the Nuclear Tests case, ${ }^{32}$ the Court bound France to its unilateral statement that atmospheric nuclear tests would soon cease, altliougli the Court never used the term "estoppel." However, it stated: "Just as the very rule of pacta sunt servanda in the law of treaties is based on good faitli, so is the binding character of an international obligation assumed by unilateral declaration." ${ }^{33}$ The Court found that binding unilateral

30. In this context, the opposite of good faith appears to be "not good faith" rather than "bad faith." See Fitzmaurice, The Law and Procedure of the International Court of Justice, 1954-9: General Principles and Sources of International Law, 35 BR1T. Y.B. INT'L L. 183, 209 (1958). This semantic difference seems to place a lighter burden on the nation making the statement, whereas "bad faith" appears to assign a higher degree of moral blame.

31. Bowett, supra note 12 , at 193.

32. Nuclear Tests (Austl. v. Fr.), 1974 I.C.J. 253 (Dec. 20).

33. Id. at 268. Pacta sunt servanda is the principle in international law that makes treaties binding. It has no corollary in municipal law because none is necessary in a system governed by a higher authority, namely the national government. See M. GREen, INTERNATIONAL LAw: LAw OF PEACE 137 (2d ed. 1982) ("Pacta sunt servanda (agreements are to be observed) is a rule which predates international law. It applies to all agreements made within the framework of the international legal system, and is the basis of the law of treaties."); G. VON GLAHN, LAW AMONG Nations: An INTROduction to Public INTERnational Law 498 (4th ed. 1981) ("One of the oldest principles in international law is one usually rendered as pacta sunt servanda: "treaties must be observed." "). 
declarations made "the State ... thenceforth legally required to follow a course of conduct consistent with the declaration." 34 According to this holding, unilateral declarations bind the state under a good faith doctrine that fosters consistency in international relations. A doctrine having such an effect would appear to be estoppel. ${ }^{35}$

Some commentators, however, have seemed to deny that the doctrine of estoppel applies to umilateral promises (as distinguished from unilateral statements of fact). Professor Fiedler has suggested that unilateral promises bind the state, but not because of estoppel: "Neither 'general principles' nor the law of treaties offer rehable and adequate bases of obligation [to abide by a unilateral promise]. . . . An answer cannot be gained by an abstract reference to good faith or estoppel." 36 Professor Bowett has discussed the international law of estoppel "only in regard to situations in which there has been an unequivocal assertion of fact (not a promise) and reliance in good faith." 37

However, ICJ decisions support the view that unilateral promises, as well as statements of fact, may give rise to an estoppel. The ICJ has limited binding unilateral declarations to those that were intended to bind. ${ }^{38}$ While establishing this limitation, the Court did not distinguish between statements of fact and promises, either of whicl could be made with the requisite intent. For example, a state might declare that another state had a valid claim and fully intend to stand by that declaration, or it might promise to recognize the other party's claim and fully intend to be bound by the promise.

Moreover, the distinction between statements of fact and promises is often unclear. ${ }^{39}$ Nuclear Tests provides a good example of the close relation between the two. The French declaration could be read as either a promise to cease testing or a statement that testing had ended. The artificiality of this distinction supports the argument that since unilateral statements of fact are binding because of estoppel, so should unilateral promises be.

34. Nuclear Tests, 1974 I.C.J. at 267.

35. To quote Justice Stanley Mosk of the California Supreme Court: "I would invoke the folk wisdom that if an object looks like a duck, walks like a duck and quacks like a duck, it is likely to be a duck." In re Deborah C., 30 Cal. 3d 125, 141, 635 P.2d 446, 455, 177 Cal. Rptr. 852, 861 (1981) (Mosk, J., concurring).

36. Fiedler, Zur Verbindlichkeit eisetiger Versprechen im Volkerrecht, 19 GER. Y.B. INT'L L. 35, 71 (1976).

37. Rubin, supra note 1 at 22; see Bowett, supra note 12 , at 196.

38. Nuclear Tests (Austl. v. Fr.), 1974 I.C.J. 253, 267 (Dec. 20).

39. Professor Fiedler says that "neither a precise definition nor a typifiable manifestation of promises can be made out." Fiedler, supra note 36, at 71 . 


\section{b. Acquiescence}

Estoppel may also arise out of a state's acquiescence to the declaration of another state or to existing circumstances. ${ }^{40}$ One commentator observes, "The few writers who have discussed the question have had no doubt that acquiescence was ... apt to found an estoppel ... provided that the circumstances were such that acquiescence could be equated with recognition or consent ...."41 If the requirements of estoppel are met, the silence binds the acquiescing state.

If the requirements are not met, acquiescence may still have a legal effect. The consequences of the silence may range "from the persuasive to the peremptory." 42 The degree of judicial importance accorded to the acquiescence will depend on whether the state's intent was clear and on whether the objecting state detrimentally relied on the other's silence. As with unilateral declarations, then, acquiescence does not always lead to an estoppel. Where it does, the state is bound to conform to its previous position; where it does not, the Court may still look to the state's acquiescence to interpret the underlying action or statement.

The first element of international estoppel, the requirement of a clear and unambiguous statement, is the greatest obstacle to estabhishing estoppel by acquiescence. By its nature, acquiescence involves no "statement." However, since it is widely accepted that an estoppel may arise from acquiescence, ${ }^{43}$ the lack of an affirmative statement presents only a semantic difficulty. Perhaps the requirement wonld be better stated as a need for a clear and unambiguous demonstration of the state's position.

Alternatively, this requirement can be viewed as a question of consent. Did the state, by its proclamations, actions, or silence, clearly and unambiguously consent at the time to the international conditions? As with the requirement of reliance, the state's consent is necessary to show a lack of good faith. If a state does not intend ${ }^{44}$ its silence to serve as a policy statement, later actions cannot be called inconsistent. "The pur-

40. Acquiescence is sometimes described as a failure to protest. See Fitzmaurice, The Law and Procedure of the International Court of Justice, 1951-4: Points of Substantive Law (pt. 2), 32 BR1T. Y.B. INT'L L. 20, 59 (1955) ("[A] failure to protest, where a protest is called for, must have a detrimental effect on the position of the party concerned ...." (footnote omitted)). See generally Stein, The Approach of the Different Drummer: The Principle of the Persistent Objector in International Law, 26 HARV. INT'L L.J. 457 (1985) (failure to object to formation of a customary rule of international law can cause acquiescing party to be bound, while, in principle, a persistent objector would not be).

41. MacGibbon, supra note 7, at 501 (footnotes omitted).

42. Id. at 502 .

43. Bowett, supra note 12, at 197-98; Fitzmaurice, supra note 40, at 59.

44. Here, as in common law tort, intent probably includes both knowing and having reason to know that a given result will occur. Good faith would seem to require a state to object where, in all likelihood, its silence would give the appearance of consent. See MacGibbon, supra note 14, at 168$69,181$. 
pose of insisting on circumspection in inferring the consent of a State from its inaction," says MacGibbon, "is to ensure that such acquiescence corresponds accurately with the implied intention of the acquiescing State ...."45 Without the requirement of consent, a state might be bound by its inaction even though it had no reason to act.

\section{B. The Use of Estoppel in the ICJ}

The World Court has bound a state by its previous actions on four occasions. Two involved unilateral declarations, ${ }^{46}$ while the other two involved acquiescence. ${ }^{47}$ In none of these cases did the Court identify the doctrine that justified its holding. However, all four contained references to good faith, consistency, or intent to be bound, language that supports an estoppel theory. In a more recent case, ${ }^{48}$ the ICJ specifically refused to apply estoppel to the facts, but the Court used language similar to that of the prior four cases, appearing to analyze the case as an estoppel problem.

\section{Eastern Greenland}

By 1933, the doctrine of estoppel in international adjudications had gained enough legitimacy to serve as the basis for a Perinanent Court of International Justice decision. The Court held in Legal Status of Eastern Greenland $^{49}$ that Norway could not object to a Danish claim of sovereiguty over Greenland because a Norwegian official previously had made a statement inconsistent with such a claim. ${ }^{50}$

The case arose out of Denmark's ongoing effort to assert such sovereiguty. After several unsuccessful attempts to convince Norway to recognize its position, Denmark communicated its willinguess to cooperate with Norway on a separate problem. In the same communique, Denmark reminded Norway of the continuing difficulties over Greenland. The Norwegian Mimister for Foreigu Affairs replied that "the Norwegian Government would not make any difficulties in the settlement of this question." 51

The Court held that although the Foreign Minister could not have meant "to be giving then and there a definitive recoguition of Danish

45. Id. at 169.

46. Nuclear Tests (Austl. v. Fr.), 1974 I.C.J. 253 (Dec. 20); Legal Status of Eastern Greenland (Den. v. Nor.), 1933 P.C.I.J. (ser. A/B) No. 53 (April 5).

47. Concerning the Temple of Preah Vihear (Cam. v. Thai.), 1962 I.C.J. 6 (June 15), and Fisheries (U.K. v. Nor.), 1951 I.C.J. 116 (Dec. 18).

48. Concerning the Delimitation of the Maritime Boundary in the Gulf of Maine Area (Can./ U.S.), 1984 I.C.J. 246 (Oct. 12).

49. (Den. v. Nor.), 1933 P.C.I.J. (ser. A/B) No. 53 (April 5).

50. Eastern Greenland, 1933 P.C.I.J. at 71.

51. Id. at 70 . 
sovereignty over Greenland,"52 Denmark had clearly sought assurances that Norway would not obstruct Danish plans for Greenland. ${ }^{53}$ The Court then concluded that the giving of such assurances by a Minister for Foreign Affairs was binding on Norway. ${ }^{54}$

Although the Court did not refer specifically to estoppel, Eastern Greenland has become the conventional starting point for a discussion of the doctrine. ${ }^{55}$ One commentator says the case shows that "[o]stensibly 'unilateral' declarations have been considered binding when made in the context of a larger negotiating situation." 56 Furthennore, the facts in the case met all the estoppel requirements: the statement was clear, voluntarily given, and relied upon. Soine question still remanis, however, as to the ineaning of the decision. Since estoppel was never mentioned by name, it is uncertain whether the Court ruled on all of the "essential" elements; nor can one know low far the Court would have been willing to go im applying the doctrine. These questions were left for later cases to resolve.

\section{Fisheries Case}

In 1951, the International Court of Justice applied the principle of estoppel in the Fisheries case. ${ }^{57}$ Once again the Court never directly announced its rehiance on an estoppel theory. Nevertheless, the holding gives a clear indication of the principle at work.

The United Kingdom brought the case to the ICJ, objecting to Norway's delimitation of its coastline along the North Sea. Simce the coastline serves as the baseline for measuring the territorial sea, Norway's delimitation extended its territorial sea riglits into what the United Kingdom considered the high seas, open to general use by all nations.

The ICJ, however, noted that "thl[e] system [of delimitation] was consistently applied by Norwegian authorities,"58 and that "[f] or a period of more than sixty years the United Kingdom Government itself in no way contested it."sg Therefore, the Court held, Norway could enforce the systein agamst the United Kingdom. ${ }^{60}$

52. Id. at 69 .

53. Id. at 71 .

54. Id. That the foreign minister made the remark may be significant. In Gulf of Maine, the actions of a career bureaucrat were held not to give rise to an estoppel, see infra notes 81-84 and accompanying text. It remains to be decided where the line should be drawn in all the layers of bureaucracy between cabinet officials and low-level functionaries.

55. See, e.g., H. Lauterpacht, The Development of International Law in the INTERNATIONAL CoURT 169 (1958); MacGibbon, supra note 7, at 485.

56. Rubin, supra note 1 , at 4 .

57. (U.K. v. Nor.), 1951 I.C.J. 116 (Dec. 18).

58. Id. at 136-37.

59. Id. at 138 .

60. Id. at 139. 
As in Eastern Greenland, one party in Fisheries was precluded from asserting a right inconsistent with its previous stance. Yet, in the latter case, the United Kingdon 1 had made no affirmative statement. Rather, its acquiescence was binding. The Court's holding that this silence bound the United Kingdonı suggests that the Court was relying on estoppel rather than on acquiescence in its weaker, interpretive form. ${ }^{61}$ Moreover, the Court specifically noted the length of time during which the United Kingdon had remained silent. This further suggests that the Court was relying on the principle of estoppel, since the longer a state remains silent, the stronger is the presumption that it consented. ${ }^{62}$

\section{Temple}

The Court's clearest application of estoppel was in 1962 in Concerning the Temple of Preah Vihear. ${ }^{63}$ The suit centered on the location of the boundary between Cambodia and Thailand. The temple, which had cultural and rehigious significance for both states, sat on a promontory in the Dangrek inountain range. This range generally served as the boundary in the region. ${ }^{64}$

In 1904, French Indochina (later Cambodia, now Kampuchea) and Siam (now Thailand) entered into an agreement under which French topographical experts were to map the frontier region. Pursuant to this agreement, the surveyors drew up eleven maps and sent them to the Siamese government. One of these represented the Dangrek range and placed the Preah Vihear promontory, along with the Temple, on the Canibodian side of the border. ${ }^{65}$

The Court held that Thailand's failure to object to this unap required it to abide by the boundary. It based this conclusion on the need for consistency in international relations, stating that "when two countries establish a frontier between them, one of the prinary objects is to achieve stability and finality. This is impossible if the line so established can, at any monient ... be called in question ...."66 Although again the judgment does not refer to estoppel specifically, this language evokes the general principle.

In separate opinions, four judges used the terms estoppel, preclusion, or acquiescence. ${ }^{67}$ The main debate within these separate opinions

61. The interpretive form of acquiescence comes into play when the requirements of estoppel by acquiescence have not all been met. Consequently, this form cannot bind the acquiescing state. See supra text accompanying note 42.

62. MacGibbon, supra note 14, at 143.

63. (Cam. v. Thai.), 1962 I.C.J. 6 (June 15).

64. Id. at 15 .

65. Id. at $20-21$.

66. Id. at 34 .

67. Id. at 39 (Separate Opinion of Judge Alfaro) (principle on which decision is based "has 
set Judge Alfaro against Judge Fitzmaurice on the necessity of reliance. ${ }^{68}$ The dissenting opinions, however, disagreed on the application of estoppel in this particular factual context. Judge Quintana contended that the text of the pertinent treaty put Preah Vihear on the Tliai side and argued that treaty texts override maps. Therefore, lie concluded, Thailand was under no "obligation to make its voice heard in response to a given fact or situation." 69 Judge Wellington Koo based his dissent on the lack of demonstrated intent by Thailand and the lack of evidence of detrimental reliance. ${ }^{70}$ Judge Spender agreed that estoppel had been too loosely applied, warning tliat " $[t]$ he concepts of recognition and acquiescence are important elements of international law. They are not likely to add to their usefulness if pushed beyond their proper content."71

\section{Nuclear Tests}

In Nuclear Tests, ${ }^{72}$ the Court declined to reach the merits upon a finding of mootness. Austratia had brought the case in opposition to France's atmospheric nuclear tests in the South Pacific Ocean. ${ }^{73}$ Before the case was heard, lowever, France declared that "the atmospheric tests which are soon to be carried out will, in the normal course of events, be the last of this type."74

The Court held that if this statement were held binding, Australia would liave to regard "its objective as liaving been achieved."75 Furthermore, it found that France "was bound to assume that other states miglit take note of these statements and rely on their being effective." 76 The Court therefore found that the statement did possess legal effect, and that the issue thus was moot. ${ }^{77}$

In its discussion of unilateral declarations, the Court stressed the importance of an intent to be bound. The Court emphasized tliat not all unilateral declarations bind the state, but that the "intention confers on

been referred to by terms of 'estoppel', 'preclusion', 'forclusion', 'acquiescence.' "); id. at 62 (Separate Opinion of Judge Fitzmaurice) ("acquiescence can operate as a preclusion or estoppel in certain cases"); id. at 97 (Dissenting Opinion of Judge Wellington Koo) (case presents no "substantial ground for application of the principle of preclusion"); id. at 131 (Dissenting Opinion of Judge Spender) ("There is a close affinity between prescription, preclusion, recognition, acquiescence and absence of protest.").

68. See supra text accompanying notes 22-26.

69. Temple, 1962 I.C.J. at 70 (Dissenting Opinion of Judge Quintana).

70. Id. at 96-97 (Dissenting Opinion of Judge Wellington Koo).

71. Id. at 131 (Dissenting Opinion of Judge Spender).

72. (Austl. v. Fr.), 1974 I.C.J. 253 (Dec. 20).

73. Id. at 256 .

74. Id. at 266 .

75. Id. at 261 .

76. Id. at 269 .

77. Id. at 272 . 
the declaration the character of a legal undertaking . ..."78 The Court also suggested a mechanism for ascertaining that intent: interpretation of the act. The Court explained, "When States inake statements by which their freedom of action is to be limited, a restrictive interpretation is called for."79 Unfortunately, the Court did not discuss the approach to be used in the more difficult cases when intent is unclear. ${ }^{80}$

\section{Gulf of Maine}

Concerning Delimitation of the Maritime Boundary in the Gulf of Maine Area ${ }^{81}$ directly presented a question of estoppel to the ICJ. It differs from the preceding cases in two respects. First, the Court in its discussion referred specifically to estoppel and acquiescence; second, the Court concluded that the doctrine of estoppel did not apply.

The case involved a boundary dispute between the United States and Canada. One Canadian arguinent sought to invoke estoppel against the United States. In the mid-1960's, the Canadian Department of Northern Affairs had corresponded with the United States Bureau of Land Management and in particular with a middle level official nained Hoffman. At one point, Hoffman received soine docuinents that purported to set the boundary in a way favorable to Canadian interests. ${ }^{82}$ Canada claimed that the United States' acquiescence to these documents estopped the United States from claiming a different boundary.

The Court, however, held that Hoffinan, a bureaucrat holding a technical job, did not have authority to accept the Canadian boundary. The Court also held that regardless of Hoffman's position, the United States was not bound by acquiescence to the docuinents since Canada should not have rehed "on the contents of a letter from an official of the Bureau of Land Manageinent ... , which concerns a technical nuatter, as though it were an official declaration of the United States . . . .83 Not all acts by other states require a response to avoid estoppel by acquiescence. Only those acts that appear binding on the declarer warrant the principle's application. ${ }^{84}$ Furthermore, this rule complies with the

78. Id. at 267 .

79. Id.

80. Governments make statements daily. Those that are most important are likely to be well planned and have the requisite "intent to be bound," but statements that appear to be of less consequence would logically have been less carefully drafted. Under these circumstances, the act does not as readily lend itself to interpretation. Another example of the difficult case would be statements made in an emergency and under severe time constraints. It is unclear whether these would be judged by the same standard.

81. (Can./U.S.), 1984 I.C.J. 246 (Oct. 12).

82. Id. at 305 .

83. Id. at 308 .

84. The Court implicitly adopted the United States' position, noting that "[a]ccording to the United States, Canada never issued an official proclamation or any other publication for the purpose 
requirement of intent, since states could hardly intend to be bound by every passing whim or off-the-cuff remark of a government functionary.

The Court supported its himitation by holding that although there was some acquiescence, there was not enough to justify the use of the estoppel doctrine: "[I]t may be conceded that the United States showed a certam imprudence in mamtaining silence ... [but] any attempt to attribute to such silence, a brief silence at that, legal consequences taking the concrete form of an estoppel, seems to be going too far." 85 The Court appeared to view estoppel as a powerful concept in imternational litigation that should not be apphied easily. The Court's conclusion does not rest solely on the short duration of the silence, for that was inentioned only briefly. Rather, the opinion language implies recognition that a doctrine as potentially powerful as estoppel requires restraint in its use.

\section{ICJ Jurisdiction by Estoppel}

None of the five ICJ cases invoking estoppel apply the principle to procedural questions such as jurisdiction. Instead, they all involve either the establishment or protection of territorial rights. Yet, theoretically, the application of the estoppel doctrine need not be so limited. States might act inconsistently regarding ICJ jurisdiction, and this mconsistency might show a lack of good faith. However, since the potential reach of the estoppel principle is so sweeping, judicial restraint is also called for. In the end, the application of estoppel to jurisdiction is neither required nor prohibited.

Commentators have, for the most part, also been reluctant to discuss this use of estoppel. The few works devoted specifically to international estoppel ${ }^{86}$ make no reference to this applicaton of the doctrine, although one commentator has advanced the view that estoppel can apply to jurisdiction. ${ }^{87}$

II

Case Concerning Military and Paramilitary ACTIVITIES IN AND AgAINST NICARAgUa

On November 26, 1984, the International Court of Justice handed

of making its claim known internationally; the United States could not, therefor infer the existence of such claims by such indirect means." Id. at 306.

85. Id. at 308 .

86. E.g., MacGibbon, supra note 14; MacGibbon, supra note 7; Rubin, supra note 1.

87. See S. Rosenne, The Law and Practice of the International Court $\S 137$, at 322 (2d rev. ed. 1985):

If State $A$ by its conduct induces in State B the belief, which is acted upon, that State A will accept, or will not contest, the jurisdiction if State B brings a certain issue before the Court for decision, then State A ought not to be permitted, subsequently, to contest the jurisdiction of the Court when that issue is brought before the Court for decision. 
down an opinion accepting jurisdiction in Concerning Military and Paramilitary Activites in and Against Nicaragua. ${ }^{88}$ Nicaragua claimed two distinct bases for jurisdiction, only one of which is discussed at length in this Comment. ${ }^{89}$

Nicaragua's primary argument supporting jurisdiction relied on the "optional clause" of the Statute of the Court. ${ }^{90}$ Article 36(2) provides that "states parties to the present Statute may at any time declare that they recoguize as compulsory ipso facto and without special agreement, in relation to any other state accepting the same obligation, the jurisdiction of the Court . ..."91 The optional clause contains the principle of reciprocity in tlie "same obligation" language. This phrase limits jurisdiction to disputes that are included in both parties' acceptance of com-

88. (Nicar. v. U.S.), 1984 I.C.J. 392 (Nov. 26). The Court's jurisdiction is governed by article 36 of the Statute of the International Court of Justice, which reads:

1. The jurisdiction of the Court comprises all cases which the parties refer to it and all matters specifically provided for in the Charter of the United Nations or in treaties and conventions in force.

2. The states parties to the present Statute may at any time declare that they recognize as compulsory ipso facto and without special agreement, in relation to any other state accepting the same obligation, the jurisdiction of the Court in all legal disputes concerning:

a. the interpretation of a treaty;

b. any question of international law;

c. the existence of any fact which, if established, would constitute a breach of an international obligation;

d. the nature or extent of the reparation to be made for the breach of an international obligation.

3. The declarations referred to above may be made unconditionally or on condition of reciprocity on the part of several or certain states, or for a certain time.

4. Such declarations shall be deposited with the Secretary-General of the United Nations, who shall transmit copies thereof to the parties to the Statute and to the Registrar of the Court.

5. Declarations made under Article 36 of the Statute of the Permanent Court of International Justice and which are still in force shall be deemed, as between the parties to the present Statute, to be acceptances to the compulsory jurisdiction of the International Court of Justice for the period which they still have to run in accordance with their terms. 6. In the event of a dispute as to whether the Court has jurisdiction, the matter shall be settled by the decision of the Court.

INTERNATIONAL COURT OF JUSTICE STATUTE art. 36.

89. The first jurisdictional claim was based on the optional clause. See infra text accompanying notes 90-119. Nicaragua's second ground for jurisdiction involved the application of the Treaty of Friendship, Commerce and Navigation, Jan. 21, 1956, United States-Nicaragua, 9 U.S.T. 449, T.I.A.S. No. 4024. See Nicaragua, 1984 I.C.J. at 426-29. The Statute of the International Court of Justice permits jurisdiction where a bilateral or multilateral treaty specifically provides for dispute resolution in the International Court. INTERNATIONAL COURT OF JUSTICE STATUTE art. 36. Nicaragua argued that this was an independent and sufficient ground for the Court to accept jurisdiction. Commentators have criticized the case as a whole, see, e.g., Note, Nicaragua v. United States in the International Court of Justice: Compulsory Jurisdiction or Just Compulsion?, 8 B.C. INT'L AND COMP. L. REV. 471 (1985), but the second asserted basis of jurisdiction is beyond the scope of this Comment.

90. In fact, Nicaragua's original pleading relied exclusively on this argument. Nicaragua, 1984 I.C.J. at 395.

91. InTERnational Court of Justice Statute art. 36(2). 
pulsory jurisdiction..$^{92}$ Jurisdiction based on this clause is commonly called "compulsory jurisdiction" because once such an optional declaration is filed, the submitting state is automatically subject to ICJ jurisdiction in future cases involving other states that have filed such a declaration.

Because of unusual circumstances surrounding Nicaragua's acceptance of compulsory jurisdiction, Nicaragua also had to plead the applicability of article 36(5), which allows transferred jurisdiction from the Permanent Court of International Justice to its successor, the International Court of Justice. Article 36(5) provides:

Declarations made under article 36 of the Statute of the Permanent Court of International Justice and which are still in force shall be deeined, as between the parties to the present Statute, to be acceptances to the compulsory jurisdiction of the International Court of Justice for the period which they still have to run in accordance with their terms. ${ }^{93}$ The two main provisions of this clause are that the treaty or convention containing the declaration must be "in force" and that the parties to the dispute must be parties to the ICJ statute.

The United States' first defense centered on whether Nicaragua had made a valid acceptance of compulsory jurisdiction. ${ }^{94}$ In 1929, Nicaragua had declared its acceptance of the conipulsory jurisdiction of the Permanent Court of International Justice. ${ }^{95}$ However, Nicaragua never deposited the ratification of this declaration with the $\mathrm{ICJ}^{96}$ and consequently was not party to the Statute. ${ }^{97}$ The true issue, however, was whetlier the acceptance of compulsory jurisdiction could act as a declaration "still in force" under article 36(5). The Umited States argued that "still in force" requires the acceptance to liave been "in force" in the first place. Nicaragua responded that the phrase "was designed to exclude from the operation of the Article only declarations that had already expired, and lia[d] no bearing whatever on a declaration, like Nicaragua's, that had not expired, but which, for some reason or anotlier, liad not been perfected."98 The Court held for Nicaragua, statnig that "Nicaragua's 1929 Declaration was valid at the monient when Nicaragua became a party to the Statute of the new Court; it lad retained its potential effect...."99

In coming to this conclusion, the Court examined the first of the two

92. Waldock, Decline of the Optional Clause, 32 BRIT. Y.B. INT'L L. 244, 256-57 (1955-1956).

93. INTERNATIONAL COURT OF JUSTICE STATUTE art. 36(5).

94. Nicaragua, 1984 I.C.J. at 400.

95. Id. at 399.

96. Id. at 400 .

97. Id. at 404 .

98. Id. at 401 .

99. Id. at 404 . 
estoppel issues. The final Report of the Permanent Court of International Justice listed Nicaragua among the states that had signed the optional clause. ${ }^{100}$ On a separate page, the Report noted that Nicaragua had not ratified the acceptance. ${ }^{101}$ The Yearbook of the International Court of Justice from 1946-47 to 1954-55 also listed Nicaragua as a state that had recognized the compulsory jurisdiction of the Court. ${ }^{102}$ Following 1956, however, the Yearbook stated that it did not appear that the League of Nations had ever received the ratification. ${ }^{103}$ In 1968, the Court began issuing a Report to the General Assembly. The first several editions of this histed Nicaragua as havmg accepted compulsory jurisdiction without mentioning the ratification problem. ${ }^{104}$

Although, as Judge Oda poimted out, neither the Yearbooks nor the Reports are binding, ${ }^{105}$ the Court used these publications to support its interpretation of article $36(5){ }^{106}$ While it clained that this application did not give the publications any added significance, ${ }^{107}$ the Court held that the thirty-eight-year acquiescence by both the U.S. and Nicaragua "unequivocally constitute[d] [their] recognition of the essential validity of the Declaration of Nicaragua of 1929 . . . A As a consequence it was recognized by both Parties that any formal defect in Nicaragua's ratification ... did not im any way affect the essential validity of Nicaragua's consent to the compulsory jurisdiction."108 Thus, without directly saying so, the Court apphied estoppel against the United States.

The United States countered with an estoppel argument of its own. It claimed that over the course of many years, Nicaragua had represented to the United States that it had not accepted the compulsory jurisdiction of the ICJ. ${ }^{109}$ In 1943, the U.S. ambassador to Nicaragua questioned the Nicaragnan Foreign Minister whether Nicaragua had ratified the siguature to the Statute of the Permanent Court of International Justice. Receiving a negative answer, the ambassador concluded that "Nicaragua is not legally bound thereby, in as much as it did not deposit

100. 16 P.C.I.J. ANN. R. (ser. E) No. 16, at 358 (1939-1945).

101. Id. at 50.

102. See, e.g., 1946-1947 I.C.J.Y.B. 111 (1947).

103. See, e.g., 1957-1958 I.C.J.Y.B. 201 n.1 (1958).

104. Concerning the Military and Paramilitary Activities in and Against Nicaragua (Nicar. v. U.S.), 1984 I.C.J. 392, 408 (Nov. 26).

105. Id. at 484 (Separate Opinion of Judge Oda) ("Relying on the inclusion of Nicaragua in the 'List of States having recognized the compulsory jurisdiction of the International Court of Justice ...' seems to overlook, or ignore the disclaimer which started in the 1956-1957 Yearbook ...."); id. at 484-85 ("The Registrar is not responsible for the legal interpretation of or implications to be drawn from [the Yearbook].").

106. Id. at 409.

107. Id.

108. Id. at 411 .

109. Id. at 413 . 
its official document of ratification with the League of Nations." 110

Another mcident that the United States claimed should estop Nicaragua imvolved a dispute between Nicaragua and Honduras. In Deceniber 1955, Honduras sought the assistance of the United States in referring the dispute to the ICJ. At this time, the Nicaraguan ambassador discussed with United States officials the fact that Nicaragua had never consented to conipulsory jurisdiction. He suggested that an agreement would have to be reached to overconie this difficulty in order to present the case to the ICJ. A few inonths later, the anibassador stated that there was "sone doubt" as to whether Nicaragua was subject to ICJ compulsory jurisdiction. ${ }^{111}$ These affirmative stateinents made by Nicaragua allegedly led the United States to beheve that Nicaragua did not consider itself subject to conipulsory jurisdiction.

The Court held, however, that Nicaragua's actions had denionstrated consent to be bound by the defective acceptance of conipulsory jurisdiction. Moreover, it found that the evidence presented by the United States was not "sufficient to overturn that conclusion, let alone to support an estoppel." 112

The United States' second defense focused on the requirenient under article 36(2) that both parties consent to jurisdiction. The United States argued that it had not accepted conpulsory jurisdiction with regard to this case. At the time the case was filed, the United States had vahidly accepted compulsory jurisdiction in general. However, in 1984, just prior to the filing of the conplamt, Secretary of State Shultz deposited a notification with the Secretary-General of the United Nations by which the United States purported to revise immediately its acceptance of con1pulsory jurisdiction to exclude disputes with Central American states. ${ }^{13}$ Consequently, the United States argued, there was no conipulsory jurisdiction over it in this case.

The United States does not appear to have been conipletely free to inake such a change. In its 1946 declaration accepting conpulsory jurisdiction, the United States included a clause stating that the declaration would reniain in effect for five years and could not be terminated except upon six months notice. ${ }^{114}$ The Umited States argued, however, that since the 1984 notification by Secretary Shultz nerely modified rather than terminated the submission to jurisdiction, this notice clause did not

110. Id.

111. Id. at 414 .

112. Id. at 414 .

113. Id. at 398.

114. "[T]his declaration shall remain in force for a period of five years and thereafter until the expiration of six months after notice may be given to terminate this declaration." 1957-1958 I.C.J.Y.B. $213(1958)$. 
apply. ${ }^{115}$

The Court found the distinction between modification and termination irrelevant, stating that the 1984 notification was "intended to secure a partial and temporary termination, namely to exempt, with immediate effect, the United States from the obligation to subject itself to the Court's jurisdiction . . .."116 It further lield that the United States was bound by the 1946 notice clause. Whether to make declarations accepting compulsory jurisdiction and how to limit them are matters within the states' discretion. 'However, the unilateral nature of declarations does not signify that the State making the declaration is free to amend the scope and the contents of its solemn commitments as it pleases."117 The Court based this liolding on the belief that the principle of good faitlı plays an important role in the optional clause system. ${ }^{18}$

The Court did not state the precise principle that makes these declarations binding. It did refer to the discussion of umiateral declarations in the Nuclear Tests case, which distinguished the binding nature of such declarations from pacta sunt servanda, the rule that makes treaties bindmg. ${ }^{119}$ The question left open is whether unilateral declarations in general, and acceptances of coinpulsory jurisdiction in particular, are binding because of estoppel or as a result of the application of some other principle with different standards.

\section{III \\ ANALYSIS}

\section{A. Jurisdiction by Estoppel in the Nicaragua Case}

\section{Nicaragua's Acceptance of Compulsory Jurisdiction}

In the Nicaragua case, the Court may have arrived at its holding on Nicaragua's acceptance of compulsory jurisdiction without reaching the issue of whether the United States was actually estopped from arguing a lack of sucli jurisdiction. The Court claimed that it liad only used acquiescence in its interpretive form, ${ }^{120}$ yet it went on to find that this silence cured any formal defects in Nicaragua's acceptance of compulsory jurisdiction. Did the ICJ apply estoppel liere?

Acquiescence legitimately can support either a metliod of interpretation or an estoppel. ${ }^{121}$ In its interpretative form, acquiescence is a factor

115. Nicaragua, 1984 I.C.J. at 415.

116. Id. at 417.

117. Id. at 418 .

118. Id.

119. Id.; see supra notes $32-33$ and accompanying text.

120. See supra note 42 and accompanying text for discussion of the interpretive form of acquiescence; supra text accompanying note 107 for the Court's disclaimer.

121. See supra note 42 and accompanying text. 
to be weighed against other evidence of the relationships and understandings involved in the dispute. In Nicaragua this process would have aided the Court in determining the effect of Nicaragua's defective acceptance by providing evidence of international reactions at the time. In its estoppel form, however, acquiescence binds the party against whom it is applied. Consequently, the requirements for applying the latter form are more stringent than those for the interpretive form.

Despite its declaration that acquiescence served only an interpretive function under the circumstances presented in Nicaragua, the Court's later discussion of the effect of the silence shows that it actually apphied the stricter version of acquiescence. The United States was estopped from objecting to Nicaragua's acceptance of coinpulsory jurisdiction. ${ }^{122}$ Not only did the Court state that the acquiescence cured technical defects in the Nicaraguan declaration (a task beyond the scope of a inere interpretive device), it also used this conduct to dismiss the United States' claim of estoppel. ${ }^{123}$ The Court clearly went beyond passive interpretation of the force of the Nicaraguan acceptance. Yet while the Court appeared to apply estoppel, it did so without examining, or even discussing, the eleinents of the doctrime. This omission may have altered the doctrine, permitting acquiescence to bind a state without all the eleinents of estoppel being fulfilled. The Court's error was in not clarifying the rationale of its holding.

The Court apparently applied estoppel although two of the doctrine's eleinents were not established. First, Nicaragua did not show that the United States clearly imtended to be bound by its acquiescence. In the Gulf of Maine case, ${ }^{124}$ the Court had held that the United States could not be bound by a declaration that was neither official nor pubhcized as a policy statement. ${ }^{125}$ Within just two months, however, the Court in Nicaragua held the United States bound by an ostensibly nonbinding administrative report. In his separate opmion, Judge Jennings noted that every volume of the Yearbook carries a disclainer that says that the inaterial published in the report " in no way involves the

122. See Briggs, Nicaragua v. United States: Jurisdiction and Admissibility, 79 AM. J. INT'L L. 373 (1985):

This conclusion-reached after careful consideration of the contrary views expressed by the United States (and, of course, the views of dissenting judges)-was based in part upon the subsequent conduct of the parties to the Court's Statute (para. 42), and the inclusion over a period of almost 40 years by international organs empowered to handle such declarations' of Nicaragua in the lists of states accepting the compulsory jurisdiction of the Court (para. 47).

Id. at 374.

123. See supra note 112 and accompanying text.

124. Concerning Delimitation of the Maritime Boundary in the Gulf of Maine Area (Can./U.S.) 1984 I.C.J. 246 (Oct.12).

125. See supra notes $83-84$ and accompanying text. 
responsibility of the Court." "126 Jennings concluded, "For the Court, nevertheless, to attach important legal consequences to entries in the Yearbook is to destroy the clear effect of the disclaimer; as well as, in my view, being wrong in principle."127

The unofficial nature of the reports could have justified the United States' silence. The Court found the United States to have acted imprudently, yet not sufficiently so to be bound, in the Gulf of Maine case, ${ }^{128}$ and could have reached such a conclusion in Nicaragua. Judge Oda criticized the Court's rehance on the reports, stating that "no one can deny that, unless there is any practical need to scrutinize specific points, little attention is likely to have been paid by other States to items which were repeated year by year." 129 The Court apphed the principle of good faith to a case that very likely amounts to hittle more than justifiable oversight. ${ }^{130}$

The Nicaragua case can also be distinguished from the four earlier ICJ cases that apphied estoppel. In at least three of those cases, ${ }^{131}$ the act leading to the estoppel occurred in the context of direct one-on-one negotiations of two states. Even in the fourth case, Nuclear Tests, ${ }^{132}$ although the binding statement was not inade directly to the adversary-state, it was clearly a response to that particular situation. The concerned state, Australia, could not fail to take notice. No such situation arose concerning Nicaragua's acceptance of compulsory jurisdiction. Nicaragua's declaration was addressed to the United Nations, not to any particular state. Nor did the stateinent arise out of a specific conflict and thereby put the adversary on notice. To find such consent here, the ICJ had to stretch the doctrine well past its historical dimensions.

Second, the reliance element was not established. Again, since the Court never directly discusses this question we do not know whether it found the requisite reliance or whether it deemed the question irrelevant.

126. Nicaragua, 1984 I.C.J. at 541 (Separate Opinion of Judge Jennings) (quoting disclaimcr).

127. Id.

128. See supra note 85 and accompanying text.

129. Nicaragua, 1984 I.C.J. at 488 (Separate Opinion of Judge Oda); see also id. at 544 (Separate Opinion of Judge Jennings) ("For the Court now to give such wcight to these entries is indeed startling. It is contrary to principle. It is at odds with the notices of disclaimer in each Yearbook, usually in more than one place. It is in any event not supported by any more than a superficial reading of the Yearbook entries.").

130. But see MacGibbon, supra note 14 , at 181 :

It has been seen that silence and inaction in any sphere of international activity in which States may have particular or general rights to protect may, under certain conditions, entail the loss of those rights. The plea of excusable ignorance of the official acts of a Statc, legislative or otherwise, has scldom been successful.

131. Concerning the Temple of Preah Vihear (Cam. v. Thai.), 1962 I.C.J. 6 (June 15); Fisherics (U.K. v. Nor.), 1951 I.C.J. 116 (Dec. 18); Legal Status of Eastern Greenland (Den. v. Nor.), 1933 P.C.I.J. (ser. A/B) No. 53 (April 5).

132. (Austl. v. Fr.), 1974 I.C.J. 253 (Dec. 20). 
It seems unlikely, however, that Nicaragua would rely on the indifference of other nations to a report concerning an issue as important to it as its own standing at the ICJ. As Judge Schwebel pointed out, Nicaragua stood in a better position to judge these reports than any other nation because Nicaragua clearly had superior knowledge of the situation. ${ }^{133}$

This poimt is related to another difficulty with the Court's holding on this issue. The "clean hands" doctrine should have been a relevant consideration. Even the Court noted that in not sending proof of ratification to the Secretary-General of the League of Nations, "Nicaragua failed to take the one step that would have easily enabled it to be counted beyond question as one of the States that had recognized the compulsory jurisdiction of the Permanent Court of International Justice."134 Nicaragua, as well as the United States and the rest of the world, also acquiesced to the Reports and Yearbooks. Judge Mosler would have apphed the clean hands doctrime to this situation: "Nicaragua ... was aware of the deficiency and could easily have clarified the situation, [but] failed to do so. It caunot take advantage of uncertainties which it knowingly left unchallenged." 135 According to this line of analysis, Nicaragua was no more entitled to the benefits of estoppel than was the Uinited States.

In spite of these considerations, the Court refused to analyze closely the United States' claim of estoppel against Nicaragua. In fact, it seems to have been willing to apply the doctrine ouly against the United States: because of its supposed acquiescence, the United States was not entitled to claim an estoppel.

The actual findings of fact in Nicaragua have only limited importance, since they apply only to that case. Yet these flaws in the Court's analysis point to a more disturbing result. The Court apparently apphied a binding estoppel against the United States although the American acquiescence did not clearly denronstrate intent, Nicaragua very well may not have rehed on this silence, and Nicaragua did not hold a superior moral position to invoke the doctrine against the United States. Because the Court did not discuss any of these issues, the international community is left to speculate as to the basis of this decision.

\section{The United States' Acceptance of Compulsory Jurisdiction}

The Court's holding that the United States was bound to abide by the six-month notice provision in its declaration accepting coinpulsory jurisdiction also lacks explanation. Instead of pointing to a justifying

133. Nicaragua, 1984 I.C.J. at 599-600 (Dissenting Opinion of Judge Schwebel).

134. Id. at 404.

135. Id. at 464 (Separate Opinion of Judge Mosler); see also id. at 600 (Dissenting Opinion of Judge Schwebel) ("Nicaragua may well be in no position to deny, after almost 40 years, what it has tolerated despite the ambiguities of which it had special knowledge."). 
principle, the Court flatly stated that as a unilateral declaration, the notice provision bound the United States. ${ }^{136}$ This is merely an assertion, not legal analysis. If unilateral declarations in general were binding under the rule of pacta sunt servanda, they would not need to meet the requirements of estoppel to create an obligation. ${ }^{137}$ If the binding nature of unilateral declarations has some other basis, estoppel requirements will probably have to be fulfilled in order to bind the declaring state. Since the Court did not make such an analysis, it remains unclear whether unilateral declarations bind because of estoppel or because of some other doctrine with unknown characteristics.

The Court did not attempt to categorize umilateral declarations or acceptances of compulsory jurisdiction. ${ }^{138}$ Judge Jennings, however, placed declarations in a category of their own:

[T]he discussion in the oral proceedings of whether or not the legal position of declarations under the Optional Clause is, or is not, governed by the law of treaties, I found not entirely helpful and in any event inconclusive. The fact of the matter must surely be that the Optional-Clause regime is sui generis. Doubtless some parts of the law of treaties may be applied by useful analogy; but so may the law governing unilateral declarations . . . . 139

In this analysis, Judge Jennings also implicitly distinguished between the binding nature of treaties and that of unilateral declarations. This distinction implies that at least general unilateral declarations bind because of a doctrine other than pacta sunt servanda-and probably because of estoppel.

If the Court categorizes acceptances of compulsory jurisdiction as treaties, then the obligation to comply rests solely on pacta sunt servanda and requires no showing of clear intent or reliance. If the Court instead classifies them as unilateral declarations, they do require such a showing. ${ }^{140}$ By claiming neither as the holding's rationale, the Court simply creates greater ambiguity in this field.

One commentator has concluded that while the United States may

136. Id. at 418 .

137. See supra note 33 and accompanying text; compare Hassan, A Legal Analysis of the United States'Attempted Withdrawal from the Jurisdiction of the World Court in the Proceedings Initiated by Nicaragua, 10 U. DAYTON L. REv. 295, 302 (1985) (declarations accepting compulsory jurisdiction are binding under law of treaties) with Wilcox, The United States Accepts Compulsory Jurisdiction, 40 AM. J. INT'L L. 699, 705 (1946) (declarations not considered treaties) and Waldock, supra note 92, at 254 (declaration considered neither multilateral nor unilateral treaty, but is instead sui generis.).

138. In its discussion of good faith, the Court referred to the Nuclear Tests case in which unilateral declarations are distinguished from pacta sunt servanda. See supra note 33 and accompanying text. However, the Nicaragua Court itself did not employ such a distinction. Nicaragua, 1984 I.C.J. at 418.

139. Nicaragua, 1984 I.C.J. at 546 (Separate Opinion of Judge Jennings); see also id. at 620 (Dissenting Opinion of Judge Schwebel) (optional clause is sui generis, and not treaty).

140. See supra text accompanying notes 32-39. 
modify or terminate its declaration, "any such action will be effective [only] on the giving of six months notice." 141 Others may extend this analysis by arguing that the Court must enforce the United States' voluntary six-month provision. However, international law and the jurisprudence of the ICJ are too complex for such easy answers. The short-term effect of binding the Uinted States to such a declaration may be insignificant, but the broader imphications of such a holding are ominous. ${ }^{142}$

\section{B. Jurisdiction by Estoppel}

Beyond the particular questions raised by the facts in the Nicaragua case, the Court's holding raises a new issue in the application of international estoppel. Can, or should, estoppel be used to estabhish jurisdiction? As discussed previously, ${ }^{143}$ the ICJ has not faced this question before; all prior applications of estoppel, both from unilateral declarations and acquiescence, used the principle to establish territorial rights. Nothing within the doctrine itself limits its use to these cases, but theoretical reasoning supports the argunent that the ICJ should not extend its application to issues of jurisdiction.

First, the establishment of territorial rights differs greatly from the establishment of jurisdiction by estoppel. For exainple, to avoid being bound by acquiescence, a state inust protest the objectionable international condition. However, a state only has standing to object when one of its vested rights has been violated. ${ }^{144}$ Territorial disputes lend theinselves to this sort of response, since the injured party clearly recognizes the infringement of its rights and has standing to complain.

Jurisdiction, however, is not a "right," and outside of specific cases before the ICJ, no particular state can claim that its "rights" with regard to jurisdiction have been violated. For example, had the United States originally filed an improper declaration accepting compulsory jurisdiction, as some have claimed it did, ${ }^{145}$ no other state in the world community would have had any particular interest in making a protest. Once the United States sues another state and tries to employ its defective acceptance, the second state has reason to coinplain of the improper United States declaration. Before that time, however, no other state has been injured or even affected at all by the United States acceptance. Only

141. Hassan, supra note 137, at 302-03.

142. See infra Part III(B). But see R. ANAND, Compulsory Jurisdiction of THE INTERNATIONAL COURT OF JUSTICE 180 (1961) (the six-month notice proviso is "important and useful" and "means that no nation [employing such a proviso] could see a dispute coming up and then and there quickly withdraw by serving a quick notice.").

143. See supra text accompanying notes 86-87.

144. MacGibbon, supra note 14 , at 167.

145. See, e.g., D'Amato, Modifying U.S. Acceptance of the Compulsory Jurisdiction of the World Court, 79 AM. J. INT’L L. 385, 392 (1985). 
injured states have any reason or standing to complain. ${ }^{146}$

The Statute of the Court supports this analysis. In article 36(1), the Statute grants jurisdiction to the Court to hear cases, and in article 38 , it defines the Court's function as deciding in "accordance with international law such disputes as are submitted to it."147 With no right violated, questions of jurisdiction cannot appear before the ICJ because the Court can only hear actual cases between states.

Second, the application of estoppel to jurisdiction circumvents the rules of the Court. Article 36 requirements for jurisdiction must be met before the Statute allows the ICJ to liear a case. ${ }^{148}$ The estoppel doctrine's wide scope, however, could allow tlie Court to grant jurisdiction irrespective of these prerequisites. This introduces a completely different, and ominous, application of estoppel. Judge Ruda recognized the error of taking this new path:

The conduct of a State is an important element in the interpretation of a convention, including the Statute, ... but it is a totally different inatter to regard this conduct as constituting acceptance of the international obligations set out in a treaty, without following the procedure laid down precisely for the entry into force of these obligations. ${ }^{149}$

Judge Ago also objected to this application of estoppel:

I must first enter an express reservation as to the very idea that the indisputable requirement of a formal act of acceptance could admissibly be replaced-and, what is more, in so special and delicate a field as acceptance of the obligation to submit one's international disputes to the jurisdiction of the Court-by mere evidence of conduct, even if the intention revealed by this conduct is not in doubt. ${ }^{150}$

In spite of the consequences of its liolding, tlie ICJ failed to heed these warnings or Judge Spender's admonition in Temple against overextendimg the principle of international estoppel. ${ }^{151}$ The Court again failed to discuss the effect or the rationale of its holding. Perhaps it did not recognize the new direction it took; perhaps it chose to omit such details for the sake of brevity; ${ }^{152}$ or perhaps it loped the issue would escape notice.

A third consideration counsels against applying estoppel to jurisdiction. Because of the lack of higlier authority in international law, con-

146. An examination of the effect of a perfection of the acceptance demonstrates this point. If, before ever invoking the faulty acceptance, the United States had modified and corrected its acceptance, no state would ever have had cause to object.

147. Compare INTERnational Court of Justice STAtute art. 36 (emphasis added) with id. art. 38 .

148. Id.

149. Nicaragua, 1984 I.C.J. at 459 (Separate Opinion of Judge Ruda).

150. Id. at 528 (Separate Opinion of Judge Ago).

151. See supra text accompanying note 71 .

152. Although this is unlikely, since the case runs 245 pages in the ICJ reports. 
sent forms the basis of the ICJ's jurisdiction. ${ }^{153}$ This basis provides "one of the biggest differences between the jurisdiction of courts within a modern state, and internationally." 154

In the case of estoppel, however, the state may not actually have consented to such jurisdiction. Judge Fitzmaurice has argued that "[t]he type of consent necessary to found international jurisdiction is, or should be, a positive one. It may arise by inference, but must, as so inferred, be seen to be something positive and definite, not open to reasonable doubt or question." 155 Yet one might well doubt whether im 1945 the Umited States contemplated, let alone consented to, jurisdiction im a 1984 case involving what the Umited States believed to be a national security matter between itself and Nicaragua. ${ }^{156}$

It could be argued that the state's action that led to the Court's finding of estoppel also demonstrates consent. Constructive consent, however, is madequate as a basis for jurisdiction im the ICJ. The state must be willing to have the case adjudicated by the Court. Otherwise the state may well withdraw from the case, ignore the Court's holding, or withdraw its acceptance of compulsory jurisdiction altogether. ${ }^{157}$

Because imternational estoppel lacks a clearly defined scope and is not a techirical rule, the Court may exercise discretion in deciding whether to apply the doctrine. This is particularly true when, as in

153. See InT'L Court of Justice, The INTERNational Court of Justice 33 (1976) (“A fundamental principle governing the settlement of international disputes is that the jurisdiction of an international tribunal depends $m$ the last resort on the consent of the States concerned."); Malloy, Objections to Adjudication in Contentious Cases Before the International Court of Justice, 5 BROOKLYN J. INT'L L. 262, 264 (1979) ("Indeed, the principle of consent of the parties as the basis of jurisdiction has long been recognized as 'a canon of international law.' " (citation omitted)).

154. Malloy, supra note 153, at 263-64 (quoting Bishop, General Course of Public International Law, 1965, 115 Hague Academy Recueil Des Cours 146, 175-76 (1965)).

155. Fitzmaurice, supra note 40 , at $89-90$. This is particularly true in cases that affect the vital interests of the State. Murphy, The World Court and the Peaceful Settlement of Disputes, 7 GA. J. INT'L \& COMP. L. 551, 557-58 (1977).

156. United States: Statemcnt on the U.S. Withdrawal from the Proceedings Initiated by Nicaragua in the International Court of Justice, 24 INT'L LEGAL MATERIALs 246 (1985) [hereinafter Statement on the U.S. Withdrawal]. The modification of the United States' declaration also demonstrates a lack of consent. One commentator has concluded, "The premise of sovereign authority readily implies that the Court shonld give full effect to the U.S. modification. A truly independent, sovereign state cannot be bound without its consent, and the modification clearly stated that the U.S. had withdrawn its consent." Note, Applying the Critical Jurisprudence of International Law to the Case Concerning the Military and Paramilitary Activities in and Against Nicaragua, 71 VA. L. REV. 1183, 1203 (1985) (footnotes omitted).

157. These are all well within the realm of possibility; the United States has done all three in response to the Nicaragua case. See infra text accompanying notes 161-62. In response to the Nuclear Tests case, France withdrew its own 1966 Declaration accepting compulsory jurisdiction. Comment, The International Court of Justice, The Nuclear Tests Cases: Judicial Silence v. Atomic Blasts, 16 HARV. INT'L L.J. 614, 636 (1975). The Court's use of estoppel there was not greeted with universal praise: "This decision not only weakens the Conrt by reducing the number of major States which have accepted the Court's jurisdiction under Article 36(2), but also damages the credibility of the Court as an international forum." Id. (footnote omitted). 
Nicaragua, the doctrine is invoked to establish a nonterritorial right. Because ICJ jurisdiction is based on the consent of the parties, the Court should exercise restraint in applying estoppel in this context. ${ }^{158}$

Nicaragua presented no compelling reasons to extend estoppel to matters of international civil procedure. But despite the paucity of support for such a result, ${ }^{159}$ the Court chose to bind the United States and permit jurisdiction under article 36(2). It did this even though this holdmg was not required to reach the result: the Court had voted fourteen to two to allow jurisdiction under the Treaty of Friendship, Commerce and Navigation. ${ }^{160}$ In effect, the Court gratuitously applied estoppel, and in doing so extended the doctrine's application into a radically new area of international law.

The Court's failure to explam its holding and rationale makes the principle of international estoppel more uncertain. Its reticence also casts doubt on the Court's purpose. Why, without a clear necessity, did the Court so expand the doctrine of estoppel? And why did it not discuss the effect of its holding?

One possible explanation is that the Court intentionally applied estoppel for the very purpose of reducing the consensual nature of jurisdiction. The Nicaragua holding does not eliminate the requirement of consent, since to be estopped the State inust demonstrate consent to the existence of some international condition, but it does dilute the jurisdiction requirement. As a result, appearance before the Court becomes more obhigatory, thereby enhancing the Court's power.

If indeed the Court intended to increase its power, it will be disappointed. As a result of the jurisdictional holding, the United States withdrew from the merits of the Nicaragua case. The Statement on the United States Withdrawal from the Proceedings Initiated By Nicaragua in the International Court of Justice gives the reason for the United States

158. E. MCWhINNEY, THE WORLD COURT AND THE CONTEMPORARY INTERNATIONAL LAW-MAKING PROCESS 63 (1979) ("The consensual basis of the Court's jurisdiction, in sharp contradistinction to all those national Supreme Courts that effectively indulge in judicial legislation, means that the Court must exercise great prudence as to invoking strained or difficult legal constructions as a ground for seeking to impose its jurisdiction upon unwilling States.").

159. Franck, Icy Day at the ICJ, 79 AM. J. INT'L L. 379, 382 (1985) ("The Court's treatment of the estoppel argument is particularly thin." (footnote omitted)). The Court ignored the warning issued by Judge Spender in Temple, see supra text accompanying note 71 , on the need for a restrained use of acquiescence. Nor did it exercise the necessary caution concerning consent to jurisdiction. See Murphy, supra note 155, at 557-58 ("Where the vital interests of a state form the basis of its refusal to participate in judicial proceedings, it is arguable that the Court must be clearly satisfied that it has jurisdiction to adjudge on the merits . ...").

160. Nicaragua, 1984 I.C.J. at 442; see also supra note 89 . Moreover, at least one commentator has concluded that "the ICJ accepted jurisdiction in this case despite the ready availability of easy grounds for non-acceptance." Recent Developments, International Court of Justice: Case Concerning the Military and Paramilitary Activities in and Against Nicaragua (Nicaragua v. United States), 26 HARV. INT'L L.J. 622, 628-29 (1985). 
departure: "Unlike domestic courts, the World Court has jurisdiction only to the extent that nation-states have consented to it. When the United States accepted the Court's compulsory jurisdiction in 1946, it certainly never conceived of such a role for the Court in such controversies." 161 Since then, the United States has also withdrawn its acceptance of the Court's coinpulsory jurisdiction, subject, of course, to six months notice. ${ }^{162}$

The Court's action, whatever its intent, has driven one of its historic supporters ${ }^{163}$ to find, in one observer's words, "that the time has come to undertake a basic rethinking of United States relations with the Court and, indeed, all multilateral institutions of world order." 164 In fact, the Court may find that power-grabbing, as possibly evidenced in Nicaragua, tends to decrease rather than enhance its overall influence. One commentator has noted that while "the enforcement problem has yet to constitute a major difficulty, ... [i]n the future the problem may heighten if the jurisdiction of the ICJ is made more compulsory and if the character and scope of its cases engage more deeply felt issues of national interest and prestige." 165 In Nicaragua, the Court clearly expanded its compulsory jurisdiction by extending estoppel to such cases. It did so under circumstances that were of such importance to the United States that the latter felt compelled to reverse forty-one years of policy regarding compulsory jurisdiction. Perhaps what is most surprising is that the Court took suclı a step with neitlier liesitation nor explanation.

\section{CONCLUSION}

International estoppel is based on the principles of good faitl and consistency in international relations. The ICJ may apply estoppel where a state voluntarily makes a clear and unambiguous statement upon which another state detrimentally relies. The doctrine has historically been applied to cases of acquiescence and also justifies the binding nature of unilateral declarations.

In the Nicaragua case, the Court made an unprecedented extension of the doctrine to the issue of jurisdiction. The ICJ applied estoppel twice against tlie United States, once to upliold tlie Nicaraguan acceptance of jurisdiction and once to invoke the United States' acceptance. In

161. Statement on the U.S. Withdrawal, supra note 156, at 247.

162. N.Y. Times, Oct. 8, 1985, at A5, col. 1 ("Officials said the American move on automatic compliance was prompted by Nicaragua's World Court case ....").

163. See Franck, supra note 159, at 379 ("[T]he U.S. Government turned its back not only on the International Court of Justice but on 40 years of leadership in the cause of world peace through law.").

164. Id. at 380.

165. Dillard, Law, Policy and the World Court-Attacking Some Misconceptions, 17 WILLAMETTE L. REv. 13, 16-17 (1980). 
so holding, the Court failed to acknowledge its reliance on the principle of estoppel and therefore did not analyze the case to determine whether the doctrine's requirements were in fact met. Furthermore, the Court did not consider the importance of its holding in relation to the scope of the doctrine of estoppel.

Although estoppel is not inherently inapplicable to jurisdictional questions, important practical and theoretical considerations dictate against such use. Jurisdiction does not involve specific rights, so nations do not have an incentive to protect themselves by protesting invalid acceptances of compulsory jurisdiction. Nor is it clear which states would be required to so protest. Moreover, the use of estoppel to claim jurisdiction goes far beyond merely adjusting the positions of the parties regarding, for example, a particular territorial question. Instead, it circumvents the rules of jurisdiction at the ICJ. States can be required to submit to the Court's jurisdiction regardless of whether the formal requirements listed in the Statute have been met, and, even though international jurisdiction is based on consent, states may be required to appear irrespective of their consent.

In its holding in Nicaragua, the Court gratuitously applied the doctrine of international estoppe ${ }^{166}$ and ignored the future effects of such a radical extension of estoppel. Since this holding, the United States has withdrawn both from the case and from the optional clause system. Perhaps a more restrained exercise of jurisdiction would not have led to such unfortunate results. In attempting to expand its compulsory jurisdiction, the Court undercut its own authority.

Megan L. Wagner*

166. See supra note 160 and accompanying text.

* B.A. 1983, University of California, Los Angeles; third-year student, Boalt Hall School of Law, University of California, Berkeley. 